\title{
Research Paper: Experience of Health Relief Team of Tabriz University of Medical Sciences in Response to the Kermanshah Earthquake (November 2017)
}

\author{
Javad Babaie $^{1^{*}}$ (D), Safa Elmi ${ }^{2}$ (D) \\ 1. Department of Health Services Management, Iranian Center of Excellence in Health Management, School of Management and Medical \\ Informatics, Tabriz University of Medical Sciences, Tabriz, Iran. \\ 2. Tabriz International Safe Community Support Center, Tabriz University of Medical Sciences, Tabriz, Iran.
}

\begin{tabular}{|l|l}
$\begin{array}{c}\text { Use yourdevice toscan } \\
\text { and read the article online }\end{array}$ & $\begin{array}{l}\text { Cftation: Babaie J, Elmi S. Experience of Health Relief Team of Tabriz University of Medical Sciences in Response to the Ker- } \\
\text { manshah Earthquake (November 2017) Health in Emergencies and Disasters Quarterly. 2021; 6(2):79-88. http://dx.doi.org/10.32598/ } \\
\text { hdq.6.2.62.4 }\end{array}$ \\
doi: $:$ http://dx.doi.org/10.32598/hdq.6.2.62.4
\end{tabular}

\section{(i) $\$$}

Article info:

Received: 16 Jan 2020

Accepted: 05 Aug 2020

Available Online: 01 Jan 2021

Keywords:

Earthquake, Experience, Health Care, Kermanshah, Response

\section{ABSTRACT}

Background: After the Kermanshah earthquake on November 12, 2017, Tabriz University of Medical Sciences dispatched a response team to the earthquake-stricken areas. This team provided the affected people with health services for 10 days. This article intends to examine the experience of this team in Kermanshah earthquake-stricken areas.

Materials and Methods: After the team's return from Kermanshah, a meeting was held to examine the challenges and review the learned lessons with 60 participants, including authorities and the people who were members of the team. The discussed issues were coded using content analysis. The similar codes were merged, and then categories were extracted.

Results: The analysis of discussions led to 9 categories of experiences that included delay in recalling process and its challenges, lack of preparedness, use of the virtual space capacity, lack of proper assessment of the health needs and the estimation of facilities, management experience of the team on the dispatch, shortcomings, and imperfections, managerial challenges, lack of coordination, and setting up of field hospitals without planning.

Conclusion: Iran is susceptible to natural disasters, and from time to time, parts of the country are affected by these disasters. One of the priorities in these disasters is people's need for health services. Since health facilities in the area usually encounter problems in these circumstances, other medical universities should provide help and relief. The present experience shows that there are still many challenges that should be addressed.

* Corresponding Author:

Javad Babaie, PhD.

Address: Department of Health Services Management, Iranian Center of Excellence in Health Management, School of Management and Medical Informatics, Tabriz University of Medical Sciences, Tabriz, Iran.

E-mail:javad1403@gmail.com 


\section{Introduction}

A

lmost all references which have been written about disasters in Iran have noted that Iran is susceptible to natural hazards induced by disasters and have stated that the size, geographical location, and climate diversity of this country increase the incidence of these disasters $[1,2]$. In the past century, around 181 disasters have occurred in Iran, which resulted in over 160000 death, more than 170000 injured, and 44 million affected people [2, 3]. In the past decade, on average, 4000 were killed, and 55000 were injured annually [3]. The occurrence of more than 10000 natural hazards in the country has been recorded for 40 years, from 1970 to 2010 [4]. Disasters are devastating events, and as a result of their destruction, the infrastructure and performance of the community are disrupted. Despite the huge amount of needs, the infrastructure services encounter problems [5, $6]$. Among these services, health care services and hospitals play the first and the most important role in providing the community with health services $[7,8]$. The timely and effective activities of hospitals can play a decisive role in the mitigation of the effects of disasters $[7,9]$.

In addition to deaths, injuries, and physical and psychological damages caused by disasters, many diseases reappear due to the interruption in health programs [10]. These programs include vaccination and disease management programs. Also, by the destruction of agricultural productions, food warehouses, and food distribution systems, food insecurity occurs. We can add to this list environmental changes, increased feeding locations of carriers, the proliferation of rodents and flies, high population displacement and their residence in busy camps with low health status, inappropriate personal health conditions, and no access to safe drinking water among the others. Therefore, health services can be very influential [8-15].

On the evening of November 12, 2017, at 21:48 local time, an earthquake happened in Kermanshah Province with a magnitude of 7.3 on Richter scale, at a focal depth of $18 \mathrm{~km}$, at a distance of $10 \mathrm{~km}$ from Ezgheleh and about $37 \mathrm{~km}$ northwest of Saralpul Zahab [14]. As a result of the earthquake, 620 were killed [15], 9388 were injured, and 70000 were made homeless. Therefore, there was a need for help and relief from other communities [16]. Since Kermanshah University of Medical Sciences (KUMS) could not respond to the quake-stricken people's needs alone, the Ministry of Health urged other universities to assist KUMS. In this regard, a team of 180 specialists and health experts from Tabriz University of Medical Sciences (TAUMS) was dispatched to the affected area in December 2017 and provided the people with health services for more than 10 days. The present study aims to learn and analyze their experiences.

\section{Materials and Methods}

After the return of the dispatched team of TAUMS from the earthquake-stricken areas of Kermanshah Province (Sarpol Zahab, Salas Babajani, and West Islamabad cities), a 3-h session was held with the participation of about 60 members of the dispatched team in TAUMS to investigate their experiences and determine the weaknesses and strengths of the relief program. The meeting was held in a friendly environment. The conversations in the meeting were recorded with the participants' permission. Then, the recorded text was transcribed verbatim and coded and analyzed utilizing content analysis. Next, the repetitive codes were deleted, and the similar codes were merged. Moreover, similar codes formed subcategories, and similar subcategories formed the main categories.

\section{Results}

The analysis of the group discussions in the 3-h session resulted in the creation of 157 codes. Merging similar codes led to the production of 85 codes. Twenty-three subcategories were developed based on these codes. These subcategories fell into 9 main categories:

1. Delay in recalling and its challenges

2. Lack of preparedness

3. Using the cyberspace capacity for risk communication

4. Lack of proper assessment of the health needs in the disaster-affected area and the estimation of facilities

5. The management experience of the team on the dispatch route

6. Shortcomings and imperfections

7. Managerial challenges

8. Lack of coordination

9. Setting up field hospitals without planning

Details of the codes, subcategories, and categories are presented in Table 1. 
Delay in the process of the call for forces and its relevant challenges

This category involved a delay in the call, lack of a prior plan, lack of criteria for selecting team members, and lack of legal obligation to be present in the team. Although all university departments were called regarding the formation of the team and its urgent dispatch to the earthquake-stricken areas, the group members were not chosen until the last minute. Many people were interested in helping but were not required to be in the team. On the other hand, there were people who, despite the need for their presence, were not dispatched at the last minute for various reasons. Moreover, the EOC of the Ministry of Health expressed various views on the composition of forces. Since there was not a legal obligation for the people to be present, some of them changed their decisions quickly. A sample of participants' comments is provided below:

"...The call for forces was made with a considerable delay...". "...Our own evaluated team was not accepted. Unfortunately, the ministry came in, intervened and formed a team of 180 people for us ..." "Unfortunately, the combination of forces until the morning of the dispatch day was not determined, that is, we had one case who volunteered in the morning of the dispatch day ..." "Until the morning of the day of dispatch, the last dispatch team was being compiled. Someone was displaced, someone called, and a group boss called and told that someone could not be present, we replaced them with someone else..."

\section{Lack of preparedness}

Lack of preparedness is a challenge that is present in nearly all disasters. It was also mentioned in this experience and had different dimensions. Its subcategories involved a lack of general preparedness of the health system, preparedness of the members of the dispatched team, preparedness of KUMS, and preparedness of TAUMS

Most of the dispatched people were not familiar with the conditions of the affected area, the probable problems in the area, and their exact responsibilities in the relevant area. There were no specific guidelines other than the Emergency Operation Center (EOP) developed by the Ministry of Health. The hospitals which were affiliated with KUMS were not familiar with interaction with supporting teams. None of the personnel, even team leaders, had not been trained to interact with the media and lacked experience in this regard. In some cases, the present reporters in the region completely debriefed them. The training was not done before, and lack of preparedness was evident in all areas. Some of the issues which the participants discussed are provided below:

“...We could not really prepare a written job description for the command team, and we could not provide the command and financial support team with this description. We presumed that everyone had sufficient information on administrative regulations...". "...The disciplinary controls of the team had not been defined, and we had gone there without preparation ... ."

The use of the cyberspace capacity for risk communication

In this experience, the cyberspace capacity enabled the team members to communicate with each other. Also, a group was formed which involved not only the members of the team but also the university staff. People shared their experiences and documentation with the other members and exchanged experiences. Announcements and calls were shared in the group, and officials at the department of university constantly monitored the performance of the team. However, due to the presence of high-ranking university officials in the group, members occasionally made some old complaints, discussed irrelevant issues in the group, and disturbed the peace in the group. A sample of the members' perspectives is provided below:

"... The presence of the dean chancellor of the university in the telegram group was both a positive and a negative aspect. The positive aspect was the colleagues' motivation and the chancellor's support. It was really effective and extremely raised the colleagues' spirits. However, it had a negative aspect." "It can be said that the chancellor was really concerned about the condition. That night, he checked the telegram group at $2 \mathrm{AM}$ and commented on the relevant issues. Moreover, he reproached us in the group."

Lack of proper assessment of the health needs of the disaster-affected area and the estimation of facilities

Although two of the university officials had gone to the affected area to assess the situation and determine their health needs, the team and the officials encountered several challenges due to inaccurate estimations. The inappropriate location of the dispatched team was one of these challenges. There was a long distance between the considered place and the field hospital, and the mem- 
bers could not commute between these places on foot. Furthermore, it lacked basic facilities. The preparation method of the food for the members had not been determined, and the team had relied on the resources of the Kermanshah University of Medical Sciences. This issue caused several problems. One of the most critical shortcomings of the assessment was the lack of prediction about the need for cars. Some of the participants' comments are provided below:

"...The accommodation facilities of the command team had not been predicted; Conex box with contact and computer facilities and the like had not been foreseen" "... We had not predicted the basic temporary facilities, heating appliances, blankets, pillows, and tents." "We had to be ready. We should have presumed that we could not find a tent to stay there even though we had identified the tents in preliminary assessments."

The management experience of the team on the dispatch route

This category involved two subcategories of accomplished measures and route challenges. To get to the destination, the team used relatively modern buses, and an administrator was chosen for each bus. The list of passengers was prepared and given to the administrators. Moreover, the commander of the team and the bus administrators were constantly in touch on the way and exchanged information. Two teams called "forerunner" and "terminal" were selected. The forerunner team moved before all other buses, and the terminal team moved behind all of the buses. Some of the dispatched employees left the area before the determined time, which caused problems for the coordination of return plans. Some drivers were not familiar with positioning systems. As a result, one of the buses lost the route and got to the destination late. It was decided to serve dinner and lunch on the way. Notwithstanding, due to the lack of an appropriate restaurant, the team commander was forced to choose two places. The selection of these places led to a waste of time and a delay in getting to the destination. Some of the participants' perspectives on this issue are provided below:

“...We had the dispatch information package." "We had provided the colleagues, bus administrators, and city administrators with the map of the relevant area." "The selection of the forerunner team and the terminal team was a positive action. These teams were not exchanged with other teams. We had a forerunner team and a terminal team before we arrived in Kermanshah. The forerunner team moved ahead of the other teams, and the terminal team moved behind them ." "We could not coordinate the team members on the way. We could not find a restaurant with enough space for 170 people. We had to find two restaurants and this issue wasted a lot of time."

\section{Shortcomings and imperfections}

The shortcomings stemmed mainly from a lack of preparedness of the personnel and the accurate assessment of the needs of the area. The team members had not been provided with individual hygiene packages and other packages for doing some things and worship. There was not a bathroom in the lodging. Moreover, the bathroom which was set up later could not be used in most cases. None of the dispatched forces were familiar with the area. Most of them had not been provided with a map of the area and encountered problems on the way in some cases. The teams lacked some of the needed essentials to offer service in the earthquake-stricken area. This issue was problematic for the team when it offered service in the relevant area.

\section{Managerial challenges}

The planning team did not consist of experienced and expert specialists. Moreover, there were no experienced people to monitor the quality of the provided clinical and health services. There was not an administrator to manage the various hospitals, and, at times, there were threats to the safety of personnel. The women's resting place was not safe in terms of security.

\section{Poor coordination}

According to the participants, there was a lack of coordination from the beginning. When the call for forces began, there was no coordination even in the preparation of uniforms, their color, and shape. The media was not informed about the dispatch of the team, and there was no centralized management of the local and the dispatched forces, and their actions were nearly independent of each other. Several field hospitals were set up in close proximity without coordination. The time of the end of the mission was not determined. Rumors were constantly spread about this issue. Eventually, some team members did not come. On the first day, the teams of the former university had left the area without coordination and delivering up the patients to the hospital. Some of the participant perspectives on this issue are provided below:

"...Unfortunately, the dear colleagues had left the area ." "...The shift along with the hospital beds hospital 
department, equipment, anesthesia department, and patients was not handed over to our team." "...Unfortunately, we did not have any information on several patients who were handed over to our team." "... It was 2 AM, imagine that, our colleagues had not slept and rested since 5 AM from the day before and had been traveling by bus."

\section{Setting up field hospitals without planning}

The universities of medical sciences, the army, and the security forces had set up two adjacent field hospitals in the earthquake-stricken areas of Sarpol Zahab. Many people went to all three hospitals on the same day. Besides, a field hospital was set up in one of the villages.

\section{Discussion}

In the aftermath of the earthquake of November 12, 2017, in Kermanshah Province, a team of 180 members consisted of specialists and general practitioners, nurses, practical nurses, and health experts, among the others, was dispatched to the cities of Sarpol Zahab, Salas Babajani, West Islamabad, and Dalaho due to the request of the Ministry of Health and Medical Education and to help KUMS to offer services to the people in earthquakestricken areas. This team provided the people with health services for about 10 days in the mentioned areas. This study examined this experience. The data analysis based on the perspectives of 60 participants in the aforementioned team led to 85 codes, 23 subcategories, and 9 categories. The main categories comprised delay in the process of the call for forces and its relevant challenges, lack of preparedness, use of the cyberspace capacity, lack of proper assessment of the health needs of the area and the estimation of facilities, the management experience of the team on the dispatch route, shortcomings and imperfections, managerial challenges, lack of coordination, and setting up field hospitals without planning.

Service capacity needs to be increased in the aftermath of disasters [17, 18]. Human resources [19] is one of the fundamental essentials for increasing the services and depends on the call for volunteer forces. In previous studies such as Gorji, Davidson, and Epstein et al., the challenges of increasing human resources, who offer help in the disaster-affected areas, have been discussed in detail. Having a baby, pregnancy, illness, and physical problems, work-related problems, family health concerns, concerns regarding one's self and the safety of property, employees' materialism and low commitment, and lack of obligation and low motivation are among these challenges. In the present study, most employees were volunteers and had high motivation. Notwithstanding, several employees did not join the team due to the above reasons.

The lack of preparedness to deal with disasters is a significant concern for many organizations and communities and has been carefully examined in previous studies [20-22]. In the earthquake which happened in Haiti, the staff believed that they were not ready for such a situation [23]. In Bahrami et al. study, the employees' prior preparedness and training with regard to the job description and the service conditions were discussed [24]. In their study, Khanke et al. emphasized the role of lack or deficiency of plans to offer health services, the need for prior preparedness, and the need to develop preparedness plans at various levels [22]. In response to the September 11 incident, it was shown that most of the people who volunteered to help the affected people did not have prior training and experience.

The lack of training harmed the volunteers themselves [25]. In examining the capabilities and limitations of Khoram Abad hospitals, it was mentioned that these hospitals lacked comprehensive and coherent action plans in disasters. Moreover, the present action plans were not implemented in an appropriate way [26]. Masoodi [23] stated that various beneficial actions had been taken to prepare the plans in the aftermath of the Bam earthquake. Nonetheless, he noted that, as shown in the earthquake in Azerbaijan, there was not complete preparedness in the health system [27]. In Nakhai et al. study, lack of prior preparedness was one of the responses of the health field to the past disasters [28]. In the present study, lack of preparedness was noticeable in all aspects of the action plan and affected all of the offered services. Tabriz University of Medical Sciences, which was hundreds of kilometers away from the affected areas, had not suffered any harm. However, it had sufficient information on the affected areas and their purpose in the mentioned areas and was aware of the range of the needed services.

Communication is one of the main components of planning, responding to disasters, and recovering from disasters. Effective communication can prevent or reduce the effects of a disaster. Therefore, the development of an active communication process should be a priority in times of disaster [29]. In the present experience, the team did not develop a plan to communicate with the media, and various individuals communicated with the media based on their prior experiences. Notwithstanding, a telegram group was formed to enable the team members to stay in touch. This group made notifications, enabled the members to share their (sometimes 
Table 1. Analysis of the experience of the health relief team dispatched by Tabriz University of Medical Sciences in response to the Kermanshah earthquake

\begin{tabular}{|c|c|c|c|c|c|}
\hline $\begin{array}{c}\text { Main } \\
\text { Category }\end{array}$ & Subcategory & Codes & $\begin{array}{c}\text { Main } \\
\text { Category }\end{array}$ & $\begin{array}{c}\text { Subcat- } \\
\text { egory }\end{array}$ & Codes \\
\hline \multirow{6}{*}{ 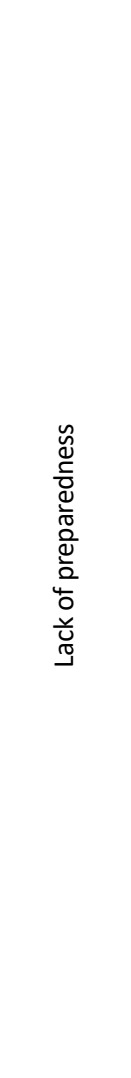 } & $\begin{array}{l}\text { Lack of pre- } \\
\text { paredness } \\
\text { of health } \\
\text { system }\end{array}$ & $\begin{array}{l}\text { Lack of job description for the dispatched } \\
\text { team members } \\
\text { Lack of preparedness of the Disaster } \\
\text { Medical Assistant Team (DMAT) teams } \\
\text { Lack of prior preparedness to carry out } \\
\text { EOP }\end{array}$ & \multirow{6}{*}{ 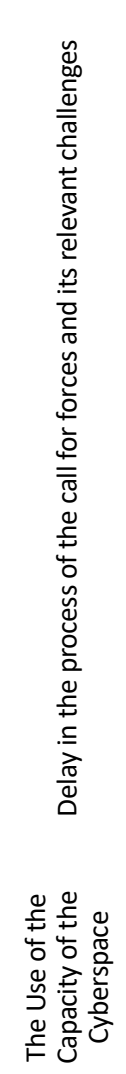 } & $\begin{array}{l}\text { Delay in } \\
\text { the call }\end{array}$ & $\begin{array}{l}\text { Delay in the call for forces } \\
\text { Lack of coordination among the net- } \\
\text { work-dispatched teams } \\
\text { Rejecting the made plans } \\
\text { The experts and putting the previously- } \\
\text { made plans aside }\end{array}$ \\
\hline & $\begin{array}{l}\text { Dispatched } \\
\text { team mem- } \\
\text { bers' lack of } \\
\text { prepared- }\end{array}$ & $\begin{array}{l}\text { Lack of familiarity of the dispatched com- } \\
\text { mand and support team and the finance } \\
\text { department with their job description } \\
\text { Lack of familiarity of the dispatched forc- } \\
\text { es with the administrative regulations } \\
\text { The dispatched team members' lack of } \\
\text { familiarity with the policies and execu- }\end{array}$ & & $\begin{array}{l}\text { Lack of } \\
\text { prior } \\
\text { plans }\end{array}$ & $\begin{array}{l}\text { The interferences of the Ministry with } \\
\text { regard to the composition of the dis- } \\
\text { patched forces } \\
\text { Lack of coordination between the dis- } \\
\text { patched teams of the university and } \\
\text { the Ministry regarding the deployment } \\
\text { of forces }\end{array}$ \\
\hline & & $\begin{array}{l}\text { tive procedures } \\
\text { The members and officials' lack of famil- } \\
\text { iarity with their job description at times } \\
\text { of crisis and disaster }\end{array}$ & & \multirow{2}{*}{$\begin{array}{l}\text { Lack of } \\
\text { criteria } \\
\text { for } \\
\text { selecting } \\
\text { team } \\
\text { mem- } \\
\text { bers }\end{array}$} & $\begin{array}{l}\text { Lack of a definite composition } \\
\text { The constant changes in the list of the } \\
\text { dispatched forces until the last mo- } \\
\text { ment }\end{array}$ \\
\hline & $\begin{array}{l}\text { Lack of pre- } \\
\text { paredness of } \\
\text { Kermanshah } \\
\text { University }\end{array}$ & $\begin{array}{l}\text { Lack of policies and executive procedures } \\
\text { due to the lack of local credit of Kerman- } \\
\text { shah University of Medical Sciences } \\
\text { Lack of preparedness of hospitals in Ker- } \\
\text { manshah }\end{array}$ & & & $\begin{array}{l}\text { Some individuals' personal interest in } \\
\text { being present in the area } \\
\text { Lack of the selection of the dispatched } \\
\text { employees based on needs and skills }\end{array}$ \\
\hline & $\begin{array}{l}\text { of Medical } \\
\text { Sciences }\end{array}$ & $\begin{array}{l}\text { Lack of convenient accommodation fa- } \\
\text { cilities } \\
\text { Lack of the prediction of disciplinary con- } \\
\text { trols in the response plan }\end{array}$ & & $\begin{array}{l}\text { Lack of } \\
\text { legal } \\
\text { obliga- } \\
\text { tion }\end{array}$ & $\begin{array}{l}\text { Lack of introduced individuals' coop- } \\
\text { eration } \\
\text { Lack of legal obligation for the pres- } \\
\text { ence of individuals }\end{array}$ \\
\hline & $\begin{array}{l}\text { paredness } \\
\text { of Tabriz } \\
\text { University } \\
\text { of Medical } \\
\text { Sciences }\end{array}$ & $\begin{array}{l}\text { team with principles of communication } \\
\text { with the media } \\
\text { Lack of exercise and sufficient training of } \\
\text { forces to deal with disasters } \\
\text { Lack of complete preparedness of the } \\
\text { dispatched teams }\end{array}$ & & $\begin{array}{l}\text { Forming } \\
\text { cyber- } \\
\text { space } \\
\text { groups }\end{array}$ & $\begin{array}{l}\text { Proper action with regard to the use of } \\
\text { social media } \\
\text { Forming a telegram group } \\
\text { The presence of the chancellor of the } \\
\text { university in the telegram group }\end{array}$ \\
\hline \multirow{3}{*}{ 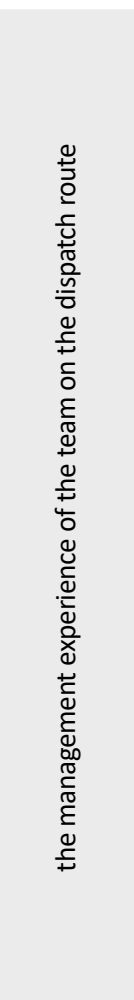 } & $\begin{array}{l}\text { Accom- } \\
\text { plished } \\
\text { Measures }\end{array}$ & $\begin{array}{l}\text { Providing the bus administrators with } \\
\text { the list of the names of individuals } \\
\text { The required predictions for deploying } \\
\text { the forces in the determined locations } \\
\text { The formation of forerunner and termi- } \\
\text { nal teams for the dispatched forces } \\
\text { Appointing administrators for the dis- } \\
\text { patched buses }\end{array}$ & 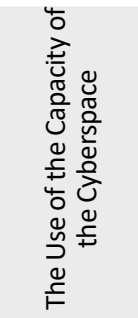 & $\begin{array}{l}\text { The ad- } \\
\text { vantages } \\
\text { and } \\
\text { disad- } \\
\text { vantages } \\
\text { of the } \\
\text { cyber- } \\
\text { space } \\
\text { group }\end{array}$ & $\begin{array}{l}\text { Several colleagues' abuse of the tele- } \\
\text { gram group } \\
\text { Dr. Soumi's monitoring of the problems } \\
\text { using the telegram group } \\
\text { Tabriz University officials' presence and } \\
\text { visit of the area }\end{array}$ \\
\hline & \multirow[b]{2}{*}{ Challenges } & \multirow[b]{2}{*}{$\begin{array}{l}\text { The change of the administrators of the } \\
\text { dispatched teams } \\
\text { The difference between the mission time } \\
\text { of some of the employees } \\
\text { Some of the employees' departure be- } \\
\text { fore the determined time } \\
\text { Dispatched team members' lack of famil- } \\
\text { iarity with the GPS system } \\
\text { Lack of the order of the buses after ar- } \\
\text { rival in Kermanshah and a missing bus } \\
\text { after arrival in Kermanshah } \\
\text { Lack of an appropriate restaurant with } \\
\text { sufficient capacity on the way } \\
\text { The waste of a lot of time due to having } \\
\text { lunch in two restaurants (the lengthy de- } \\
\text { lay of the dispatched forces) }\end{array}$} & \multirow{2}{*}{ 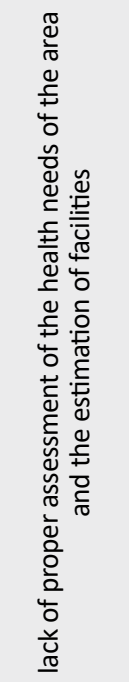 } & $\begin{array}{l}\text { Inac- } \\
\text { curate } \\
\text { assess- } \\
\text { ment }\end{array}$ & $\begin{array}{l}\text { The inappropriate procedure of the } \\
\text { quick assessment } \\
\text { Assessors' lack of familiarity with the } \\
\text { principles of assessment }\end{array}$ \\
\hline & & & & $\begin{array}{l}\text { Incom- } \\
\text { plete } \\
\text { estima- } \\
\text { tion of } \\
\text { facilities }\end{array}$ & $\begin{array}{l}\text { Inappropriate location of the teams in } \\
\text { Kermanshah } \\
\text { Lack of the map of the area and its lack } \\
\text { of availability for the teams in the area } \\
\text { Lack of the prediction of the temporary } \\
\text { basic facilities for the dispatched forces } \\
\text { of the university } \\
\text { Inappropriate condition of the area } \\
\text { Lack of the prediction of the cooking } \\
\text { facilities for the dispatched forces } \\
\text { Lack of the prediction of the cars for } \\
\text { the dispatched teams } \\
\text { Lack of the prediction of the accom- } \\
\text { modation facilities for the dispatched } \\
\text { command forces of universities } \\
\text { Lack of the examination of the special } \\
\text { border features of the area }\end{array}$ \\
\hline
\end{tabular}




\begin{tabular}{|c|c|c|}
\hline $\begin{array}{c}\text { Main } \\
\text { Category }\end{array}$ & Subcategory & Codes \\
\hline $\begin{array}{c}\text { Manage- } \\
\text { rial chal- } \\
\text { lenges }\end{array}$ & $\begin{array}{l}\text { Managerial } \\
\text { challenges }\end{array}$ & $\begin{array}{l}\text { Lack of experienced forces in the plan- } \\
\text { ning group of the dispatched team } \\
\text { Lack of the use of the experienced indi- } \\
\text { viduals' knowledge and experience } \\
\text { Lack of an experienced group to monitor } \\
\text { the quality of clinical, non-clinical, and } \\
\text { health services } \\
\text { Pursuing other aims instead of offering } \\
\text { help to people in the earthquake-affect- } \\
\text { ed area } \\
\text { Lack of the appointment of supervisors } \\
\text { for the dispatched teams of universities } \\
\text { for the Sarpol Zahab Hospital } \\
\text { Insecurity of women's resting place } \\
\text { The security problem of the earthquake- } \\
\text { affected areas due to the existence of } \\
\text { Daesh and Pezhvak forces }\end{array}$ \\
\hline
\end{tabular}

\begin{tabular}{|c|c|c|}
\hline $\begin{array}{c}\text { Main } \\
\text { Category }\end{array}$ & $\begin{array}{c}\text { Subcat- } \\
\text { egory }\end{array}$ & Codes \\
\hline & $\begin{array}{l}\text { Lack of } \\
\text { essential } \\
\text { personal } \\
\text { equip- } \\
\text { ment }\end{array}$ & $\begin{array}{l}\text { Lack of individual hygiene packages, } \\
\text { and lack of spiritual and cultural pack- } \\
\text { ages, along with the lack of prayer fa- } \\
\text { cilities for the dispatched forces } \\
\text { Inappropriate accommodation loca- } \\
\text { tion } \\
\text { Lack of bathrooms }\end{array}$ \\
\hline
\end{tabular}

ings and

imperfec-

tions

Lack of

Essen-

The dispatched team members' lack of familiarity with the area

for the dispatched forces Lack of the prediction of the forms of performance report and statistics

Lack of

forces

The dispatched team members' lack of skill and capability

Scarcity of skilled and expert forces

Lack of

coordi-

nation in

the pro-

cess of

dispatch

Lack of coordination of the command team

Lack of similar uniforms of the dispatched teams of the University of Tabriz and lack of the prepared uniforms Lack of coordination of the farewell of the command team

Lack of notification regarding the university dispatch

Lack of coordination with the News Departments and the dispatched team members' debriefing by the reporters

Lack of The necessity of coordination with the

coordi-

nation

among

universi-

ties in

Setting up various field hospitals without considering their essential principles

Lack of forces for the management of the
Setting

up field

hospitals

without

planning
The man- People's tendency to go to the main agement hospital of Sarpol Zahab due to cultural of field issues

The large number of patients who went to the hospital after the earthquake Lack of coordination among the field hospital administrators local officials and forces

Non-centralized management of the local and non-local forces

Lack of a call for the local forces of the earthquake-affected area in two weeks Lack of discipline of high-ranking officials in Kermanshah Province in the assessment of the needs

Lack of

coordi-

nation Officials' lack of coordination regarding
setting up field hospitals and providing them with personnel

Lack of coordination regarding the notification of the end of the operation

regard Lack of coordination of the command to the team regarding the deployment of offer of forces in the earthquake-affected areas services The lack of a single command team in the crisis and disasters

Lack of handing the shift over to the dispatched forces

Scarcity of the received equipment

Lack of Lack of the handover of the patients

coordi- who were in a critical condition

nation in The dispatched team members' lack of handing adequate rest

the field The handover of the night shift of the hospitals hospital at the time of the arrival in the over to area

the team The departure of the Shiraz team without coordination

The handover of the patients without having information on their condition

\section{Health in}

Emergencies and |D]isasters [Oluarterly 
incomplete) experiences with the other members, and informed the officials of the matters. Moreover, there are experiences in the world, including using the capacity of the Twitter messenger [30]. To offer any service in disasters and to formulate interventions, it is essential to identify the problems and needs of the region, including health needs, appropriately [31] because, in most cases, there is insufficient information on these issues. Furthermore, the present information might not be useful [32]. To overcome this problem, rapid assessment of needs in the disaster-affected areas is usually carried out. The needs assessment is a technical issue and requires specific skills and tools, and should be carried out by experienced individuals [31]. In the present study, certain assessments had been carried out. Notwithstanding, their inaccuracy caused several problems. In previous studies, the researchers have discussed these challenges in detail [31-33]. Nearly all of the previously experienced problems were encountered in the present case.

Receiving assistance from other areas and organizations in times of disaster will continue for all of the major disasters in the future. As mentioned earlier, this issue stems from the fact that the created health needs cannot be satisfied by the available services and capacities in the disaster-affected areas. These processes will be challenging, mainly if they are not carried out according to initial plans. Therefore, the timely response and effectiveness of this kind of assistance depend on prior preparedness (including the preparedness of human resources, the preparedness of equipment, the availability of instructions and guidelines, and managerial capacities) and coordination between the contributing areas the disaster-affected area. It is hoped that these kinds of preparations are made and practiced at times of peacefulness and the managerial coordination be improved and accelerated at times of disaster.

\section{Ethical Considerations}

\section{Compliance with ethical guidelines}

All ethical principles are considered in this article.

\section{Funding}

This research did not receive any grant from funding agencies in the public, commercial, or non-profit sectors.

\section{Authors' contributions}

Both authors equally contributed to preparing this article.

\section{Conflict of interest}

The authors declared no conflict of interest.

\section{Acknowledgments}

The authors would like to thank the Tabriz University of Medical Sciences relief team who was involved in the Kermanshah earthquake.

\section{References}

[1] Araghizadeh H, Saghafi Nia M, Entezari V. [Analyzing medical management in disasters: A review of the Bam Earthquake experiences (Persian)]. Journal of Military Medicine. 2004; 5(4):259-68. http:/ / militarymedj.ir/article-1-156-en.html

[2] Ardalan A, Sabzghabaie A, Najafi A, Zonoobi V. [Hospital disaster risk assessment (Persian)]. Tehran: Moaffag; 2012 http:// www.old.piho.ir/UploadedFiles/gFiles/e4cb8cccc4b7403.pdf

[3] Khankeh HR. [Hospital preparedness plan: National hospital preparedness program (Persian)]. Tehran: University of Social Welfare and Rehabilitation Sciences; 2014. https://vct. iums.ac.ir/files/vct/files/ketab_Amadegi_bimarestani_final___.pdf

[4] Ardalan A, Kandi M, Osooli M, Shamseddini A, Zare M, Moosavand AK. [Profile of natural hazards in IR Iran (Persian)]. Tehran: Raznhan Publications; 2011. https://vch.iums. ac.ir/files/vch/files/risk_assessment_in_PHC.pdf

[5] Khankeh HR, Mohammadi R, Ahmadi F, Maddah S, Ranjbar M, Khodaie MR. [Management of health care services at time of natural disasters (Persian)]. Archives of Rehabilitation. 2006; 7(25):49-55. http://rehabilitationj.uswr.ac.ir/ article-1-48-en.html

[6] Khankeh HR, Mohammadi R, Ahmadi F. [Barriers and facilitators of health care services at the time of natural disasters (Persian)]. Archives of Rehabilitation. 2005; 6(1):23-30. http:// rehabilitationj.uswr.ac.ir/article-1-96-en.html

[7] Maleki M, Shojaie P. [Hospitals preparation in disasters: Security (Persian)]. Journal of Health Administration. 2007; 10(28):65-70. http://jha.iums.ac.ir/article-1-32-en.html

[8] Djalali AR, Casteren M, Hosseini jenab V, Khatib M, Ohlen G, Kurland L. Hospital Incident Command System (HICS) performance in Iran: Decision making during disasters. Scandinavian Journal of Trauma, Resuscitation and Emergency Medicine. 2012; 20(14). [DOI:10.1186/1757-7241-20-14] [PMID] [PMCID]

[9] Arab M, Zeraati H, Akbari Haghighi F, Ravangard R. [A study on the executive managers' knowledge and performance, and their hospitals preparedness against earthquake events and their relationships at public hospitals (affiliated by Tehran University of Medical Sciences (TUMS) 2005-2006) (Persian)]. Journal of Health Administration. 2009; 11(34):714. http://jha.iums.ac.ir/article-1-323-en.html 
[10] Djalali A, Hosseinijenab V, Hasani A, Shirmardi K, Castrén M, Öhlén G, Panahi F. A fundamental, national, medical disaster management plan: An education-based model. Prehospital and Disaster Medicine. 2012; 24(6):565-9. [DOI:10.1017/ S1049023X00007524] [PMID]

[11] Bissell RA, Pinet L, Nelson M, Levy M. Evidence of the effectiveness of health sector preparedness in disaster response: The example of four earthquakes. Family \& Community Health. 2004; 27(3):193-203. [DOI:10.1097/00003727200407000-00006] [PMID]

[12] Powers R, Daily E, WADEM. International disaster nursing. Cambridge: Cambridge university press; 2010. https:// www.worldcat.org/title/international-disaster-nursing/ oclc/439600331

[13] Ardalan A, Vatandoost H, Akbari Sari A, Gouya MM, Babaie J. [Performance assessment of communicable disease management in natural disasters in I.R. Iran (Persian)] [PhD.dissertation]. Tehran: Tehran University of Medical Sciences; 2015.

[14] Ghanjal A, Bahadori M, Ravangard R. An overview of the health services provision in the 2017 Kermanshah earthquake. Disaster Medicine and Public Health Preparedness. 2019; 13(4):691-4. [DOI:10.1017/dmp.2018.139] [PMID]

[15] Ostadtaghizadeh A, Khaleghy Rad M, Aghababaeian H, Zare M, Kamranzad F. Earthquake in Western Iran: Renovation Kills. PLoS Currents. 2018; 10. [DOI:10.1371/currents.dis. ac10620db4a0c944e605c4c226a75f64] [PMID] [PMCID]

[16] Guha-Sapir D, Hoyois Ph, Below R. Annual disaster statistical review 2014: The numbers and trends. Centre for Research on the Epidemiology of Disasters (CRED). Louvain-laNeuve, Belgium: Ciaco Imprimerie; 2015. https:/ / www.cred. be/sites/default/files/ADSR_2015.pdf

[17] Milsten AM. Volunteersand donations. In: Ciottone GR, Keim ME, Darling RG, Anderson PH, Heide AD, Jacoby I, Noji E, et al, editors. Disaster medicine. $2^{\text {th }}$ ed. Philadelphia: Mosby Elsevier; 2015. https://www.google. com/books/edition/Ciottone_s_Disaster_Medicine/ GBzmCgAAQBAJ?hl=en\&gbpv $=0$

[18] Epstein RH, Ekbatani A, Kaplan J, Schechter R, Grun Wald Z. Development of staff recall system for mass casulty incidents using cell phone text messaging. Anesthesia \& Analgesia. 2010; 110(3):871-8. [DOI:10.1213/ANE.0b013e3181cb3f9e] [PMID]

[19] Barbisch D, Haik J, Tessine A, Hanfling D. Surge capacity. In: Koenig KL, Schultz CH, editors. Disaster medicine. Cambridge: Cambridge University Press; 2010. [DOI:10.1017/ CBO9780511902482.005]

[20] Talati S, Bhatia P, Kumar A, Gupta AK. OjhaCD. Strategic planning and designing of a hospital disaster manual in a tertiary care, teaching, research and referral institute in India. World Journal of Emergency Medicine. 2014; 5(1):35-41. [DOI:10.5847/ wjem.j.issn.1920-8642.2014.01.006] [PMID] [PMCID]

[21] Zhong Z, Clark M, Hou XY, Zang Y, FitzGerald G. Progress and challenges of disaster health managementin China: A scoping review. Global Health Action. 7(1):24986. [DOI:10.3402/gha.v7.24986] [PMID] [PMCID]

[22] Khankeh HR, Khorasani-Zavareh D, Johanson E, Mohammadi R, Ahmadi F, Mohammadi R. Disaster health-related challenges and requirements: A grounded theory study in Iran. Prehospital and Disaster Medicine. 2011; 26(3):151-8. [DOI:10.1017/S1049023X11006200] [PMID]
[23] Masoudi Alavi N. Disaster: Are We Prepared? Nursing and Midwifery Studies. 2014; 3(2):e19993. [DOI:10.17795/ nmsjournal19993]

[24] Bahrami M, Alliakbari F, Aein F. Iranian nurses' perception of essential competences in disaster response: A qualitative study. Journal of Education and Health Promotion. 2014; 3:81. [DOI:10.4103/2277-9531.139247]

[25] Crane MA, Levy-Carrick NC, Crowley L, Barnhart S, Dudas M, Onuoha U, et al. The response to September 11: A disaster case study. Annals of Global Health. 2014; 80(4):320-31. [DOI:10.1016/j.aogh.2014.08.215] [PMID]

[26] Malekshahi F, Mardani M. [Abilities and limitations of crisis management in Shohadaye Ashayer and Social Security hospitals of Khorramabad in 2007 (Persian)]. Iranian Journal of Critical Care Nursing. 2008; 1(1):29-34. https:/ / www.sid. ir/en/journal/ViewPaper.aspx?id=168827

[27] Pouraghaei M, Jannati A, Moharamzadeh P, Ghaffarzad A, Far MH, Babaie J. Challenges of hospital response to the twin earthquakes of August 21, 2012, in East Azerbaijan, Iran Disaster Medicine and Public Health Preparedness. 2017; 11(4):422-30. [DOI:10.1017/dmp.2016.153]

[28] Nakhaei M, Khankeh HR, Masoumi G, Hosseini MA, Parsa-Yekta Z. [Health management in disasters in Iran: A qualitative study (Persian)]. Health in Emergencies and Disasters. 2015; 1(1):33-42. http:/ /hdq.uswr.ac.ir/article-1-78-en.html

[29] Houston JB1, Hawthorne J, Perreault MF, Park EH, Goldstein Hode M, Halliwell MR, et al. Social media and disasters: A functional framework for social media use in disaster planning, response, and research. Disasters. 2015; 39(1):1-22. [DOI:10.1111/disa.12092] [PMID]

[30] Murthy BP, Krishna N, Jones T, Wolkin A, Avchen RN, Vagi SJ. Publichealth emergency risk communication and social media reactions to an errant warning of a ballistic missile threat-Hawaii, January 2018. Morbidity and Mortality Weekly Report. 2019; 68(7):174-6. [DOI:10.15585/mmwr. mm6807a2] [PMID] [PMCID]

[31] Babaie J, Moslehi S, Ardalan A. Rapid health needs assessment experience in August 112012 East Azerbaijan earthquakes: A qualitative study. PLoS Currents Disasters. 2014 [doi:10.1371/currents.dis.308f6140d54f78fd1680e2b9e6460ae3]

[32] Ardalan A, Holakoee Naieni K, Aflatoonian MR, Nekoie Moghadam M, Laporteh R, Noji E. [Experience of a community based needs and health status assessment in Bam earthquake (Persian)]. Iranian Journal of Epidemiology. 2005; 1(1,2):33-45. http:/ /irje.tums.ac.ir/article-1-203-en.htm

[33] Chan EY. Evidence-based public health practices: challenges for health needs assessments in disasters. Hong Kong Medical Journal. 2006; 12(4):324-6. https://ora.ox.ac.uk/objects/uuid:c7c33dab-a2d9-41d9-86db-4363c7b2beeb 
This Page Intentionally Left Blank 